\title{
The effect of integrated tillage of light soil on potato yields
}

\author{
Ryszard Walkowiak ${ }^{1}$, Stanisław Podsiadłowski ${ }^{2}$, Michał Czajka \\ ${ }^{1}$ Department of Mathematical and Statistical Methods, Poznań University of Life Sciences, \\ Wojska Polskiego 28, 60-637 Poznań, Poland, e-mail: ryszard.walkowiak@up.poznan.pl \\ ${ }^{2}$ Institute of Biosystems Engineering, Poznań University of Life Sciences, Wojska Polskiego 50, \\ 60-627 Poznań, Poland, e-mail: stapod@up.poznan.pl
}

\section{SUMMARY}

\begin{abstract}
Excessive compaction of soil has an adverse effect on its aggregate structure, and as a result also on the yields of various crops. To prevent this negative impact, diverse methods of limited tillage are applied. However, these methods are not effective when cultivating sandy soils of very low natural porosity. An original integrated tillage method for such soils has been developed at the Poznan University of Life Sciences. This paper presents a comparison of yields and quality of three popular potato cultivars following the application of conventional and integrated tillage methods. The experiment shows that integrated tillage contributes to an increase in potato yield by providing better conditions for tuber growth.
\end{abstract}

Key words: Traditional tillage, integrated tillage, factorial design, potato cultivars, yield.

\section{Introduction}

Excessive soil compaction has an adverse effect on water and air relations, availability of water and nutrients, root growth and water infiltration (Mocek et al. 1994, Starczewski et al. 1984, Grzebisz 1989, Busschner, Lipiec 1993). All of these factors result in decreased yield. Yield reduction caused by excessive soil compaction has been observed in such crops as maize (Busschner, Lipiec 1993), sugar beet (Li, Kromer 1994), potatoes (Starczewski et al. 1984), barley and wheat (Dzienia et al. 1990, Hoffman-Kąkol et al. 1989), oats (McAfee et al. 1989), strawberries and carrots (Lipiec, Simota 1994). However, the effect of soil compaction on yields is strongly dependent on the availability of water and 
nutrients. In years with these conditions the effect may be completely eliminated (Grzebisz 1989).

A considerable increase in soil compaction leads to an increase in the amount of strongly bound water, i.e. water sparsely available for plants. The proportion of this type of water is dependent on soil texture. The heavier and more varied in terms of grain size is a given soil, the greater the proportion of physiologically unavailable water (Domżał 1979). As a result, yields are reduced.

In recent decades the development of agricultural engineering has produced machines of considerable dimensions and mass (Kooistra, Tovey 1994). The mass of tractors used in Central Europe ranges from 3 to $13 \mathrm{Mg}$, while that of combine harvesters may be as high as $18 \mathrm{Mg}$ (Lipiec, Simota 1994). During the passage of such heavy machinery, free spaces in the soil's aggregate structure are deformed, disrupted or completely destroyed (Kooistra, Tovey 1994).

Conventional tillage methods require repeated tractor passages, which may cause soil compaction at considerable depths. Results of numerous studies show that the depth of the zone deformed by the wheels of tractors and their implements may be as much as $0.3-0.4 \mathrm{~m}$, with maximum compaction at a depth of $0.2-0.25$ m (Krasowski et al. 1981).

Reduced tillage is a method to prevent excessive soil compaction. For instance, direct seeding (no tillage) methods are proposed, taking advantage of the relatively high natural porosity of tilled soils (Crovetto 1996). They are recommended particularly for soils with relatively high natural porosity (Davies 1985, Watts and Dexter 1993, Young and Mullins 1991). In turn, light soils, such as the loamy sands found commonly in the Wielkopolska region (Poland), have relatively low natural porosity. They are typically cultivated intensively, with a considerable role in crop rotation played by plants responding poorly to low porosity of topsoil during the initial vegetation period and - generally - to its high cohesion (Pabin et al. 2000). In view of the aforementioned factors it was decided in 1996 to undertake studies on integrated tillage technology, serving to reduce erosion risk for heterogeneous soils while maintaining intense production (Podsiadłowski and Hagen 2000). These studies were conducted in cooperation 
with USDA, and in succeeding years they were financed by the Ministry of Science and Higher Education and the National Centre for Science and Development.

Integrated tillage consists in simultaneous ploughing, fertiliser broadcasting, secondary tillage and crop seeding or planting. All of these operations are performed by one aggregate for integrated tillage. Advantages of integrated tillage include:

- Considerable fuel conservation (over 50\%). The tractor travels only over soil still retaining its cohesive structure, which entails much lower rolling resistance than passage over ploughed, soft soil. Moreover, ploughing, rolling, fertiliser broadcasting and cereal sowing or root crop planting are performed during a single passage of aggregate equipment.

- Improved, much more uniform emergence rates and greater yields of cereals. Elimination of ploughed soil compaction considerably enhances capillary ascent of soil water and ensures uniform soil porosity, optimal for plant growth.

- Relatively high mechanical strength of the newly formed aggregate structure, which reduces the probability of wind erosion (Czajka et al. 2010).

The aim of this study was to verify whether integrated tillage improves the yield and tuber structure of potatoes grown mainly on light soils.

\section{Material and methods}

Experiments were conducted on a field of approx. $7 \mathrm{ha}$. The location was selected, among other things, due to the relatively flat and almost uniform relief, suggesting that soil moisture content should be more or less identical throughout the entire field. In terms of arable land classification, the analysed soil represents quality class IVa - arable land of medium quality, better (Strzemski 1972); and in terms of agricultural quality, complex 5 - good rye complex.

The experiments were conducted for a period of two years. Those years had very dry springs. In the period of two months after planting, i.e. in April and May, 
total precipitation in the first year was $83 \mathrm{~mm}$, while in the second year it was $73 \mathrm{~mm}$.

Potatoes were planted using the integrated tillage technology, with an aggregate farming machine set for integrated tillage (Figure 1), composed of a plough, a fertiliser distributor, a Campbell roller and a potato planter.

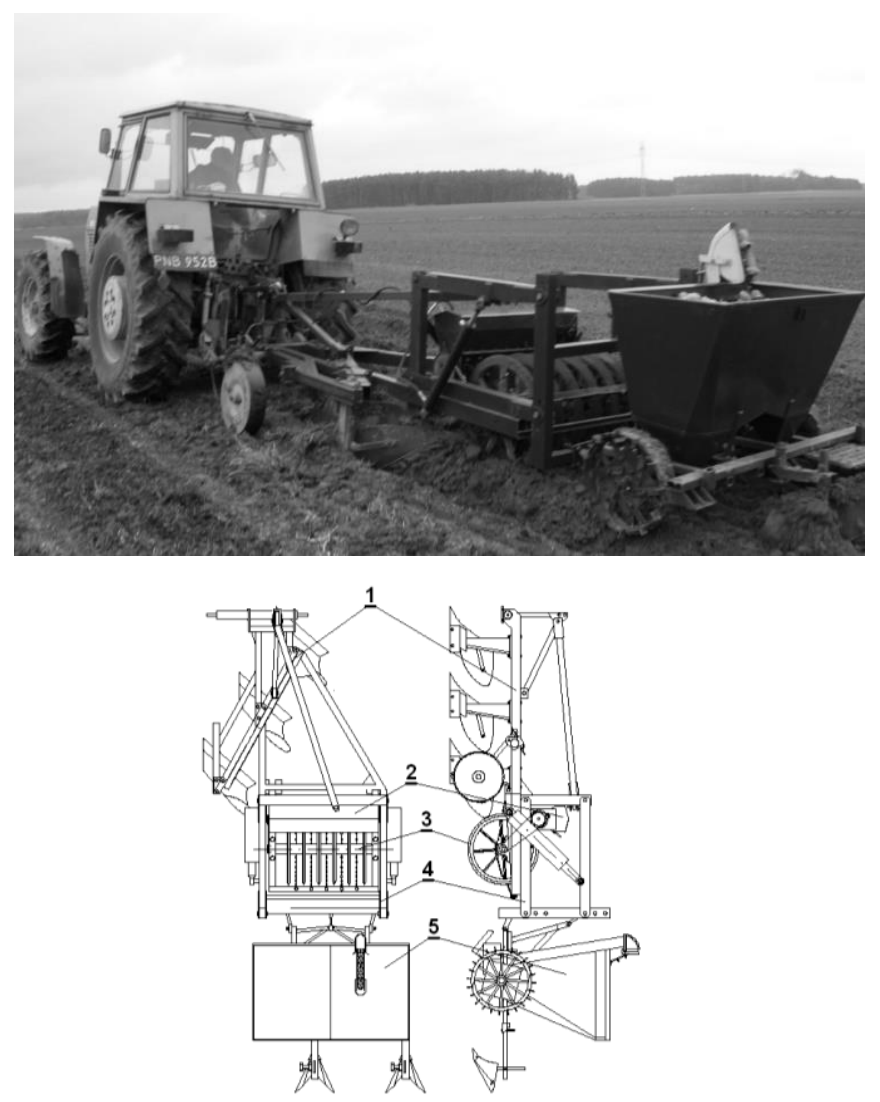

Figure 1. Aggregate machine set for integrated tillage, adapted for potato planting: 1 -ploughing implement, 2 - fertiliser distributor, 3 - Campbell roller, 4 - auxiliary frame, 5 - cup potato planter (author's photo).

The type and dosage of fertilisers in both types of tillage were the same, consistent with good agricultural practices. After potato planting, all cultivation activities after integrated tillage were carried out in the same way as traditional ones. 
Data on potato yields $(\mathrm{kg} / \mathrm{ha})$ were analysed statistically. The analyses were conducted on the cultivars Bellarosa, Jelly and Satina, and two tillage technologies: conventional and integrated. For all data collected in both years, an analysis of variance was applied for a three-factor experiment with interaction, in which yield per hectare was the investigated variable subject to the following factors: year (two levels); cultivar (three levels); tillage (two levels).

The following model was applied:

$$
\mathrm{y}_{i j k}=\mu+\alpha_{i}+\beta_{j}+\gamma_{k}+(\alpha \beta)_{i j}+(\alpha \gamma)_{i k}+(\beta \gamma)_{j k}+(\alpha \beta \gamma)_{i j k}+\mathrm{e}_{i j k},
$$

where $i=1,2, j=1,2,3, k=1,2, \mathrm{y}_{i j k}$ is the observation of potato yield for the $i$-th year, $j$-th cultivar and $k$-th tillage variant, $\mu$ is the mean yield of potatoes, $\alpha_{i}$ is the main effect of the $i$-th year, $\beta_{j}$ is the main effect of the $j$-th cultivar, $\gamma_{k}$ is the main effect of the $k$-th tillage variant, $(\alpha \beta)_{i j}$ is the effect of interaction of the $i$-th year with the $j$-th cultivar, $(\alpha \gamma)_{i k}$ is the effect of interaction of the $i$-th year with the $k$-th tillage variant, $(\beta \gamma)_{j k}$ is the effect of interaction of the $j$-th cultivar with the $k$-th tillage variant, $(\alpha \beta \gamma)_{i j k}$ is the effect of interaction of $i$-th year with $j$-th cultivar and $k$-th tillage variant, $\mathrm{e}_{i j k}$ is the random error for observation $\mathrm{y}_{i j k}$. Random errors are assumed to have normal distributions with uniform variance.

Next the analysis of variance was conducted for yields per hectare for each of the years separately. This was analysis of variance for a two-factor experiment with interaction, in which the factors were: cultivar (three levels) and tillage (two levels).

A modified model (1) was applied, from which the main effects of years and interaction effects involving years were eliminated.

In the second year the structure of potato tubers (their diameter) was analysed. In accordance with the Ordinance of the Minister of Agriculture (2003) tubers with a diameter less than $3 \mathrm{~cm}$ are of non-merchantable grade. Considering market requirements, some buyers treat tubers with a diameter of less than $4 \mathrm{~cm}$ as non-merchantable. Research results (Nowacki 2010) indicate high demand for large tubers with a diameter of more than $6 \mathrm{~cm}$. For this reason the tuber structure analyses included percentage shares in yields per hectare for tubers with 
diameters in the following ranges: less than $3 \mathrm{~cm}$, from 3 to $4 \mathrm{~cm}$, from 4 to $6 \mathrm{~cm}$, and more than $6 \mathrm{~cm}$.

Thus in each experimental variant four random variables were tested:

- $\mathrm{x} 1$ - percentage share in yield per hectare for tubers such that $\mathrm{s}<3 \mathrm{~cm}$;

- $\mathrm{x} 2$ - percentage share in yield per hectare for tubers such that $3 \leq \mathrm{s}<4 \mathrm{~cm}$;

- $\mathrm{x} 3$ - percentage share in yield per hectare for tubers such that $4 \leq \mathrm{s}<6 \mathrm{~cm}$;

- $\mathrm{x} 4$ - percentage share in yield per hectare for tubers such that $\mathrm{s} \geq 6 \mathrm{~cm}$ where $\mathrm{s}$ denotes tuber diameter.

The field was divided into 36 plots: 2 tillage methods (conventional and integrated) $\times 3$ cultivars (Jelly, Satina and Bellarosa) $\times 6$ replications. In every plot three ridges were selected, from each of which one plant was selected at random and dug out. The entire yield was weighed. The mean yield of the three selected plants constituted one observation. In this way $2 \times 3 \times 6=36$ observations were obtained from $36 \times 3=108$ plants.

In order to conduct the analysis of variance for the factorial experiments, observations expressed in percentage of yield were transformed into Bliss probits using the formula $\mathrm{y}=\operatorname{arc} \sin \left((\mathrm{x} / 100)^{1 / 2}\right)$.

It is clear that the variables $x_{i}, i=1, \ldots, 4$, are dependent: the sum of their values in individual experimental units is 100 . Thus, for each of these variables, a separate analysis of variance was conducted for the factorial experiment with interaction in which the factors were: tillage variant (two levels) and cultivar (three levels).

\section{Results}

\subsection{Analysis of potato yields}

First, observations of yield were analysed statistically following the assumptions of a three-factor experiment, model (1), with the following factors: year (two levels); cultivar (three levels: Bellarosa, Jelly, Satina); tillage (two levels: conventional and integrated tillage). 


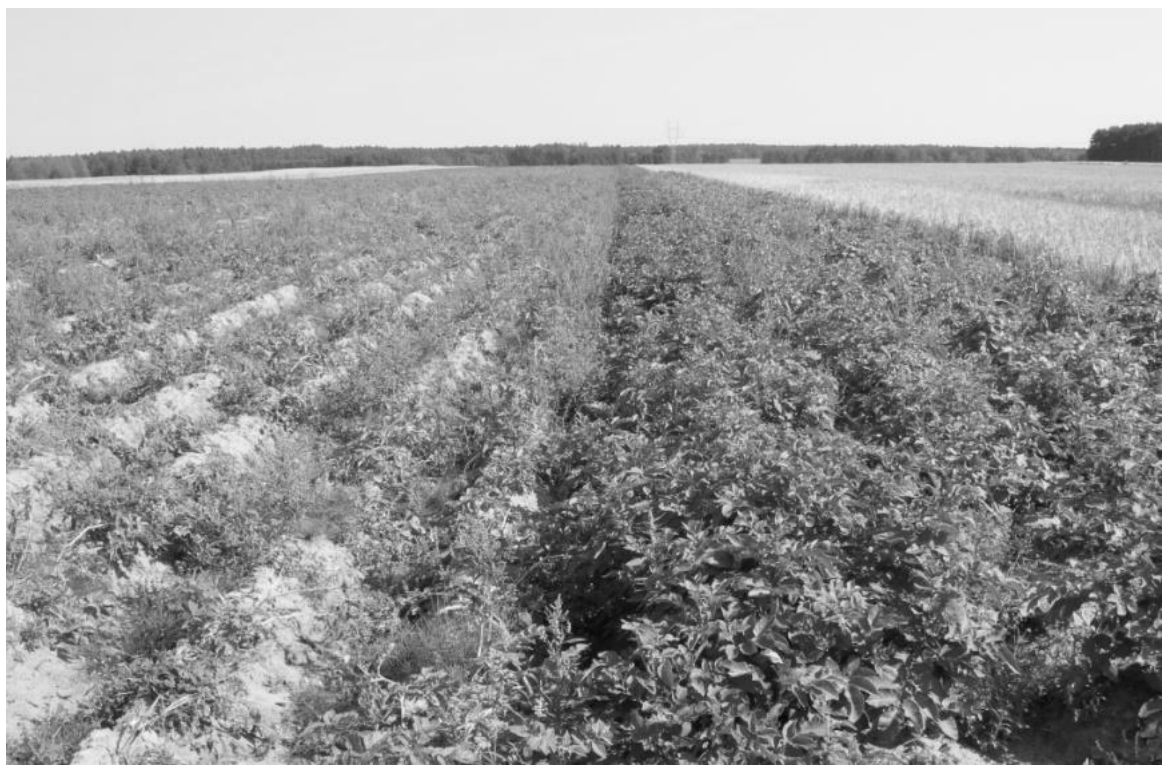

Figure 2. Comparison of the condition of potatoes planted using the conventional method (left-hand side) and integrated method (right-hand side) fifteen weeks after planting on light soil at limited precipitation (author's photo).

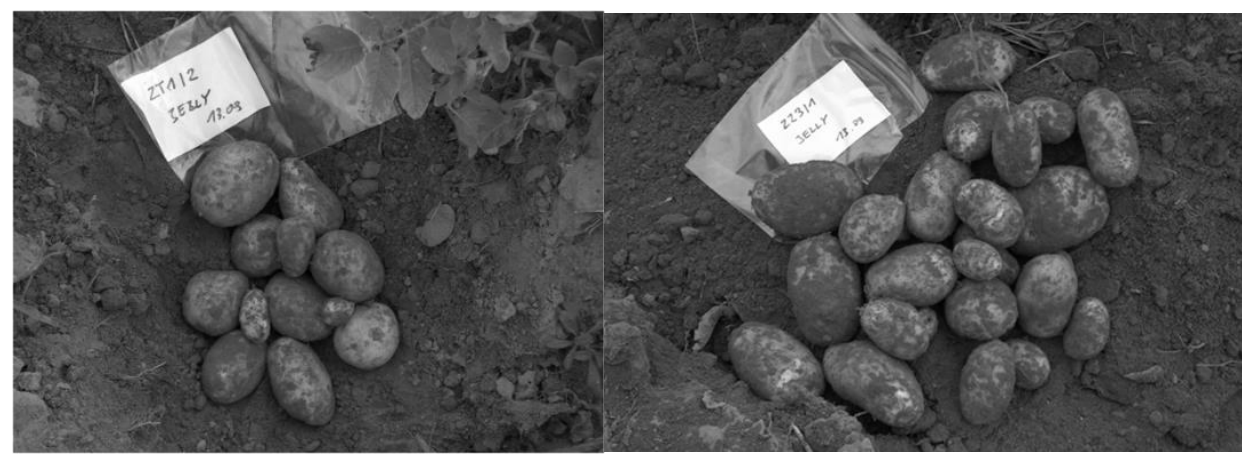

Figure 3. Example yields from one plant of potato cv. Jelly under the conventional (left-hand side) and integrated method (right-hand side) (author's photo).

The results of analysis of variance are given in Table 1. As the table shows, years, cultivars and tillage variants were factors having a significant effect on yields. 
Table 1. Results of analysis of variance for yields of three potato cultivars in the years 2008-2009.

\begin{tabular}{cccccc}
\hline Source of variation & SS & Df & MS & F & p \\
\hline Year & $9.609280 \mathrm{E}+08$ & 1 & $9.609280 \mathrm{E}+08$ & 4.8290 & $0.033174^{*}$ \\
Cultivar & $1.697646 \mathrm{E}+09$ & 2 & $8.488231 \mathrm{E}+08$ & 4.2656 & $0.020120^{*}$ \\
Tillage & $2.092566 \mathrm{E}+09$ & 1 & $2.092566 \mathrm{E}+09$ & 10.5158 & $0.002233^{* *}$ \\
Year $\times$ Cultivar & $3.099924 \mathrm{E}+08$ & 2 & $1.549962 \mathrm{E}+08$ & 0.7789 & 0.464997 \\
Year $\times$ Tillage & $1.546644 \mathrm{E}+08$ & 1 & $1.546644 \mathrm{E}+08$ & 0.7772 & 0.382673 \\
Cultivar $\times$ Tillage & $3.488218 \mathrm{E}+08$ & 2 & $1.744109 \mathrm{E}+08$ & 0.8765 & 0.423235 \\
Year $\times$ Cultivar $\times$ Tillage & $9.525163 \mathrm{E}+07$ & 2 & $4.762582 \mathrm{E}+07$ & 0.2393 & 0.788147 \\
Error & $8.954677 \mathrm{E}+09$ & 45 & $1.989928 \mathrm{E}+08$ & & \\
\hline
\end{tabular}

$*$ denotes significance of effects at $\alpha=0.05$

** denotes significance of effects at $\alpha=0.01$

Mean yields for individual tillage variants for both years jointly and for all the cultivars jointly are presented in Figure 4.

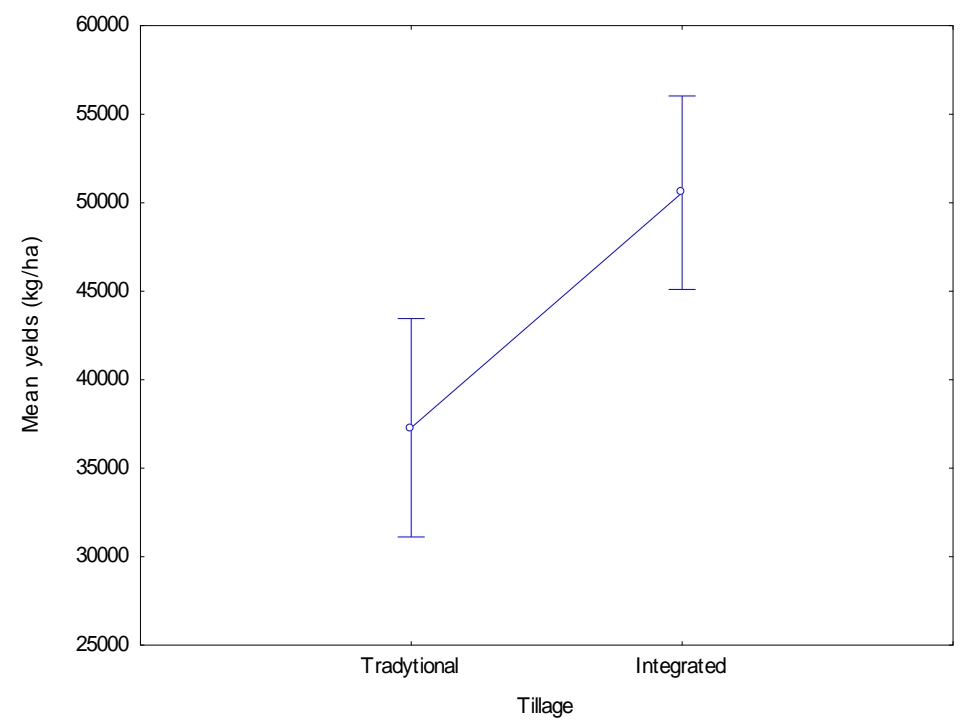

Figure 4. A comparison of potato yields obtained after conventional and integrated tillage.

In the years of analysis, in the case of integrated tillage all of the cultivars produced significantly higher yields compared with conventional tillage.

It can be seen from Table 1 that all interactions turned out to be nonsignificant. Thus it may be concluded that responses of yield to tillage in the case of individual cultivars were comparable in both years. 
In order to analyse the response of yields of the tested cultivars to integrated tillage, analysis of variance for a two-factor experiment was conducted for each year separately, with the following factors: cultivar (three levels) and tillage (two levels).

The results of this analysis for the first year are given in Table 2. Analysis showed that cultivar and tillage technology have a significant effect on yields. However, their interaction turned out to be non-significant.

Table 2. Results of analysis of variance for yield of three potato cultivars in the first year.

\begin{tabular}{cccccc}
\hline Source of variation & SS & Df & MS & F & p \\
\hline Cultivar & $1.139464 \mathrm{E}+09$ & 2 & $5.697321 \mathrm{E}+08$ & 4.6390 & $0.025765^{*}$ \\
Tillage & $1.283489 \mathrm{E}+09$ & 1 & $1.283489 \mathrm{E}+09$ & 10.4507 & $0.005207 * *$ \\
Cultivar $\times$ Tillage & $4.828598 \mathrm{E}+07$ & 2 & $2.414299 \mathrm{E}+07$ & 0.1966 & 0.823489 \\
Error & $1.965023 \mathrm{E}+09$ & 16 & $1.228139 \mathrm{E}+08$ & & \\
* denotes significance of effects at $\alpha=0.05$ & & & \\
** denotes significance of effects at $\alpha=0.01$ & & &
\end{tabular}

In the first year integrated tillage led to highly significantly greater yields than conventional tillage for all of the cultivars jointly (Figure 5).

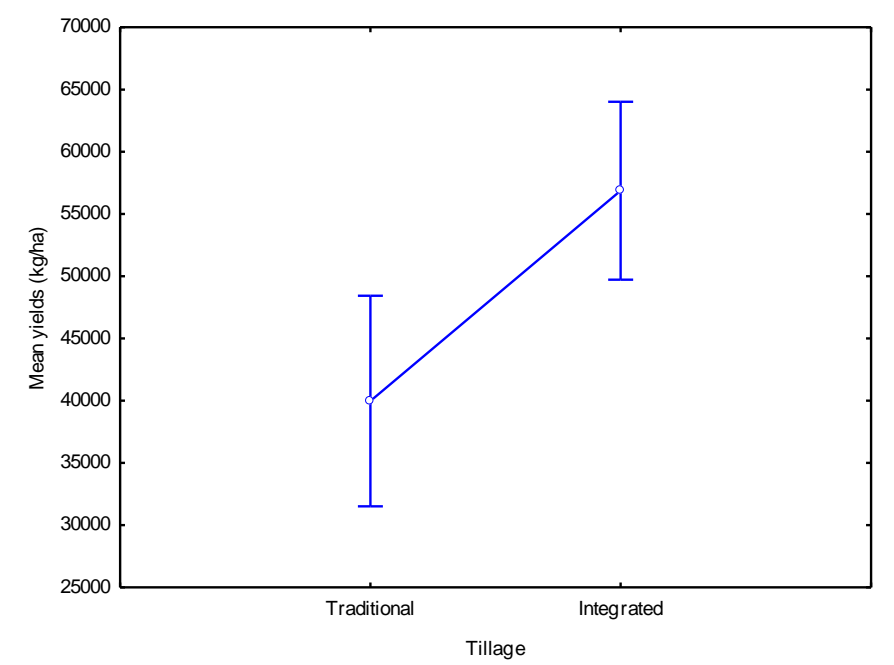

Figure 5. A comparison of potato yields in terms of tillage variant in the first year. 
Similar results were obtained using an analogous analysis of yields obtained in the second year.

\subsection{Analysis of tuber structure}

Basic statistics for the percentage shares of tubers with diameters of less than 3 $\mathrm{cm}$, from 3 to $4 \mathrm{~cm}$, from 4 to $6 \mathrm{~cm}$ and over $6 \mathrm{~cm}$ are presented in Table 3 .

Table 3. Basic statistics

\begin{tabular}{ccccccc}
\hline Variable & Tillage & Mean & Median & Minimum & Maximum & $\begin{array}{c}\text { Standard } \\
\text { deviation }\end{array}$ \\
\hline $\mathrm{x}_{1}$ & Conventional & 4.28835 & 3.66972 & 0.350877 & 10.76000 & 2.97535 \\
$(\mathrm{~s}<3 \mathrm{~cm})$ & Integrated & 4.38979 & 2.35746 & 0.00000 & 14.44444 & 4.91481 \\
$\mathrm{x}_{2}$ & Conventional & 15.48232 & 10.03584 & 3.424658 & 79.64912 & 17.47466 \\
$(3<\mathrm{s}<4 \mathrm{~cm})$ & Integrated & 6.98086 & 6.37374 & 0.57471 & 17.75701 & 5.32612 \\
$\mathrm{x}_{3}$ & Conventional & 74.30221 & 80.55000 & 6.666667 & 92.53000 & 19.55484 \\
$(4<\mathrm{s}<6 \mathrm{~cm})$ & Integrated & 62.05544 & 65.29271 & 40.22770 & 85.81818 & 11.97307 \\
$\mathrm{x} 4$ & Conventional & 5.92536 & 5.61404 & 0.000000 & 21.58273 & 6.13332 \\
$(\mathrm{~s}>6 \mathrm{~cm})$ & Integrated & 26.57391 & 28.05790 & 0.00000 & 58.06452 & 15.11428 \\
\hline
\end{tabular}

The graph for diameters is given in Figure 6.

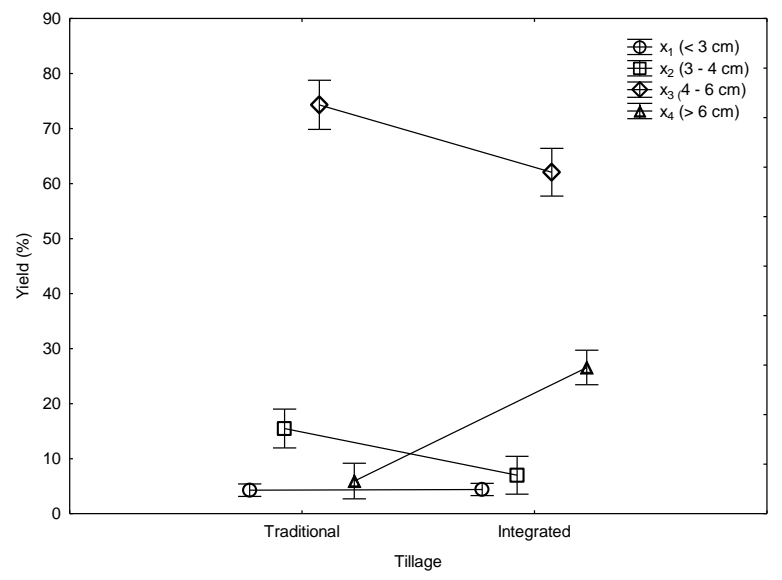

Figure 6. Mean shares of individual grades in potato yields. Whiskers denote $95 \%$ confidence intervals.

Results of analysis of variance conducted for each of the variables $\mathrm{x}_{\mathrm{i}}$, $\mathrm{i}=1,2,3,4$, separately are presented in Tables 4, 5, 6 and 7. 
Table 4. Results of analysis of variance for variable $\mathrm{x}_{1}$

\begin{tabular}{cccccc}
\hline Source of variation & SS & Df & MS & F & $\mathrm{p}$ \\
\hline Free term & 3.511651 & 1 & 3.511651 & 348.5778 & $0.000000^{* *}$ \\
Cultivar & 0.221566 & 2 & 0.110783 & 10.9967 & $0.000049^{* * *}$ \\
Tillage & 0.019026 & 1 & 0.019026 & 1.8885 & 0.172470 \\
Cultivar×Tillage & 0.007598 & 2 & 0.003799 & 0.3771 & 0.686830 \\
Error & 0.997348 & 99 & 0.010074 & & \\
\hline
\end{tabular}

** denotes significance of effects at $\alpha=0.01$

Table 5. Results of analysis of variance for variable $\mathrm{x}_{2}$

\begin{tabular}{cccccc}
\hline Source of variation & SS & Df & MS & F & $\mathrm{p}$ \\
\hline Free term & 8.398847 & 1 & 8.398847 & 1371.464 & $0.000000^{\text {*** }}$ \\
Cultivar & 0.465423 & 2 & 0.232712 & 38.000 & $0.000000^{\text {*** }}$ \\
Tillage & 0.173189 & 1 & 0.173189 & 28.280 & $0.000001^{\text {** }}$ \\
Cultivar×Tillage & 0.023408 & 2 & 0.011704 & 1.911 & 0.153498 \\
Error & 0.587904 & 96 & 0.006124 & & \\
\hline
\end{tabular}

** denotes significance of effects at $\alpha=0.01$

Table 6. Results of analysis of variance for variable $\mathrm{x}_{3}$

\begin{tabular}{cccccc}
\hline Source of variation & SS & Df & MS & F & $\mathrm{p}$ \\
\hline Free term & 101.0318 & 1 & 101.0318 & 3240.055 & $0.000000^{* *}$ \\
Cultivar & 0.4021 & 2 & 0.2011 & 6.448 & $0.002331^{\text {** }}$ \\
Tillage & 0.5406 & 1 & 0.5406 & 17.337 & $0.000067^{* *}$ \\
Cultivar×Tillage & 0.0315 & 2 & 0.0158 & 0.505 & 0.604819 \\
Error & 3.0870 & 99 & 0.0312 & & \\
\hline
\end{tabular}

** denotes significance of effects at $\alpha=0.01$

Table 7. Results of analysis of variance for variable $\mathrm{x}_{4}$

\begin{tabular}{cccccc}
\hline Source of variation & SS & Df & MS & F & $\mathrm{p}$ \\
\hline Free term & 12.57595 & 1 & 12.57595 & 399.6426 & $0.000000^{\text {*** }}$ \\
Cultivar & 0.42781 & 2 & 0.21391 & 6.7976 & $0.001713^{\text {*** }}$ \\
Tillage & 2.94351 & 1 & 2.94351 & 93.5399 & $0.000000^{\text {** }}$ \\
Cultivar×Tillage & 0.09127 & 2 & 0.04564 & 1.4502 & 0.239455 \\
Error & 3.11533 & 99 & 0.03147 & & \\
\hline
\end{tabular}

** denotes significance of effects at $\alpha=0.01$

It can be seen from Tables 4, 5, 6 and 7 and from Figure 6 that tillage method does not influence the percentage share of the smallest potato grade in the total 
yield, but has a significant effect on the shares of all of the other grades. We conclude from comparison of shares of particular grades in the yields produced in the conventional and integrated tillage systems that:

- tillage technology has no significant effect on the shares of tubers with diameters of less than $3 \mathrm{~cm}$ in potato yields;

- the share of the grade with diameters of 3-4 $\mathrm{cm}$ in potato yields produced after conventional tillage is highly significantly greater than after integrated tillage;

- the share of the grade with diameters of 4-6 cm in potato yields produced after conventional tillage is highly significantly greater than after integrated tillage;

- the share of the grade with diameters of more than $6 \mathrm{~cm}$ in potato yields produced after conventional tillage is highly significantly smaller than after integrated tillage.
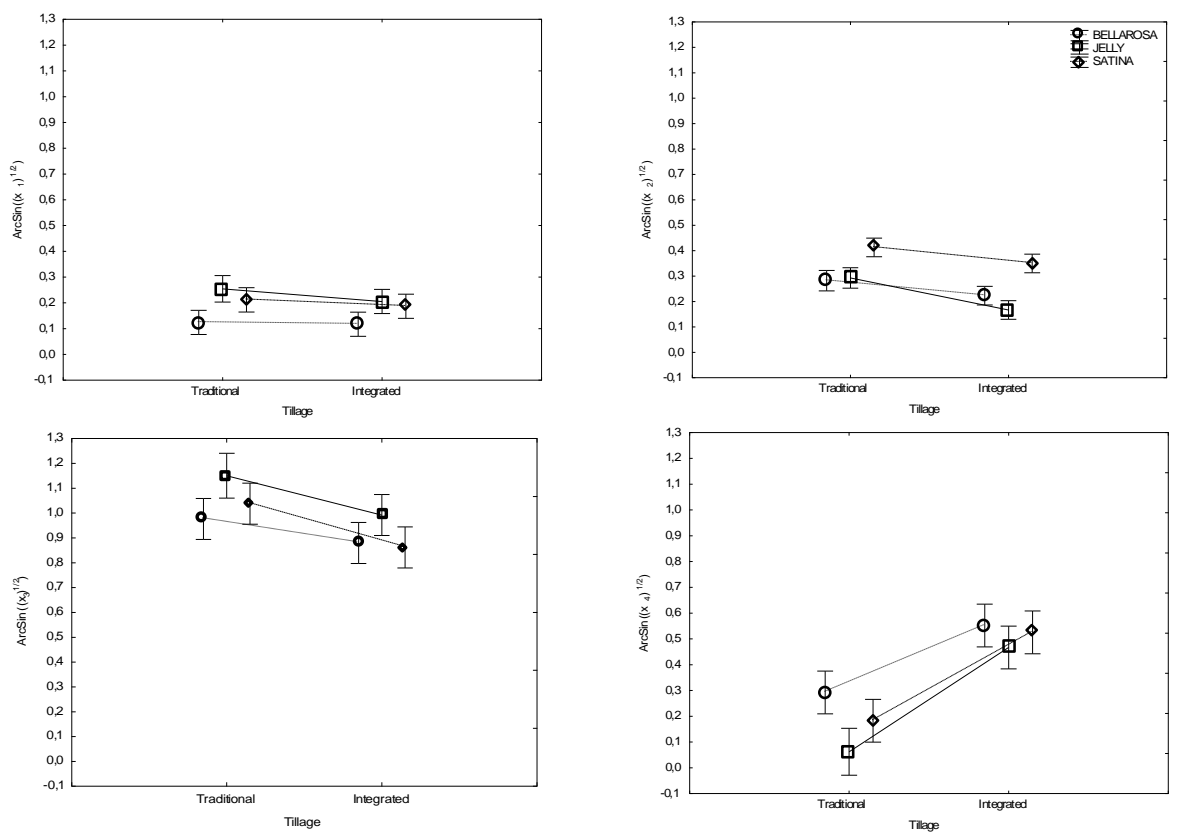

Figure 7. Cultivar $\times$ Tillage interaction 
The cultivar $\times$ tillage interaction for all grades of tubers proved to be nonsignificant, i.e. the shares of all grades in all potato cultivars respond similarly to a change in tillage technology. The shares of the grades with diameters of 3-4 cm and $4-6 \mathrm{~cm}$ produced after conventional tillage are always greater than after integrated tillage, while the share of the grade with diameters of more than $6 \mathrm{~cm}$ after conventional tillage is always smaller than it is after integrated tillage (Figure 7).

\section{Conclusions}

Factors having a significant effect on potato yields included year, cultivar and tillage variant.

In the analysed years, in the case of all potato cultivars, integrated tillage led to significantly higher yields than conventional tillage.

The percentage of tubers with diameters greater than $6 \mathrm{~cm}$ was highly significantly smaller after conventional tillage than after integrated tillage, while the percentages of tubers with diameters of 3-4 cm and 4-6 cm were significantly greater after conventional tillage than after integrated tillage. The shares of the non-merchantable grade of tubers $(<3 \mathrm{~cm})$ in the yields after integrated and conventional tillage did not differ significantly.

This means that integrated tillage, promoting capillary ascent in soil, contributes to an increase in yields of potatoes by providing better conditions for tuber growth.

\section{REFERENCES}

Busschner W., Lipiec J. (1993): Early growth of maize in compacted soil with fine and coarse structure. Int. Agrophysics 7: 77-83.

Crovetto C.L. (1996): Stubble over the Soil. ASA, WI 53711 USA: p. 237.

Czajka M., Podsiadłowski S., Walkowiak R., Wojciechowski T. (2010): Integrated tillage as anti-erosion soil tillage: research prospect. TEKA Komisji Ochrony i Kształtowania Środowiska Przyrodniczego 7: 5-11.

Davies P. (1985): Influence of organic matter content, moisture status and time after reworking on soil shear strength. J. Soil Science 36: 299-306. 
Domżał H. (1979): Wpływ zagęszczenia gleby na zawartość wody silnie związanej oraz retencję wody produkcyjnej i użytecznej [The effect of soil compaction on content of strongly bound water and retention of productive and useful water]. Roczniki Gleboznawcze 7, XXX(3): 45-72.

Dzienia S., Sosnowski A., Hoffman-Kąkol I. (1990): Wpływ ugniatania gleby i roślin przez ciągniki na fizyczne właściwości gleby, zachwaszczenie oraz plony jęczmienia i pszenicy. Cz. I. Zmiany niektórych właściwości fizycznych gleby [The effect of soil and plant compaction by tractors on physical properties of soil, weed infestation and yields of barley and wheat. Part I. Changes in selected physical properties of soil]. Roczniki Nauk Rolniczych, Ser. A, vol. 107, book 4: 21-29.

Grzebisz W. (1989): Wzrost korzeni roślin uprawnych w glebie zagęszczonej [The growth of roots of crop plants in compacted soil]. Fragm. Agron. 6(3): 19-31.

Hoffman-Kąkol I., Dzienia S., Sosnowski A. (1989): Wpływ ugniatania gleby i roślin przez ciągniki rolnicze na fizyczne właściwości gleby, zachwaszczenie oraz plony jęczmienia jarego i pszenicy jarej. Cz. II. Zmiany w zachwaszczeniu i plony [The effect of soil and plant compaction by tractors on physical properties of soil, weed infestation and yields of barley and wheat. Part II. Changes in weed infestation and yields]. Roczniki Nauk Rolniczych, Ser. A, vol. 108, book 1: 101-111.

Kooistra M.J., Tovey N.K. (1994): Effects of Compaction on Soil Microstructure. In: Soil Compaction in Crop Production. Eds.: B.D. Soane, C. Van Ouwerkerk, ELSEVIER, Amsterdam: 91-109.

Krasowski E., Skwarek W., Karczewski T., Przesmycki J. (1981): Wpływ mechanizmów jezdnych ciągników rolniczych na odkształcenia gleby w procesie jej uprawy [The effect of vehicle propulsion of agricultural tractors on soil deformation in the process of its tillage]. Rocz. Nauk Roln. 75, Ser. C, 2: 101-111.

Li C.H., Kromer K.H. (1994): The effect of sugar beet cultivation system on soil compaction. Int. Agrophysics 8: 87-91.

Lipiec J., Simota C. (1994): Role of Soil and Climate Factors in Influencing Crop Responses to Soil Compaction in Central and Eastern Europe. In: Soil Compaction in Crop Production. Eds.: B. D. Soane, C. Van Ouwerkerk, ELSEVIER, Amsterdam: 365-390.

McAfee M., Lindström J., Johansson W. (1989): Effects of Pre-sowing Compaction on Soil Physical Properties, Soil Atmosphere and Growth of Oats on a Clay Soil. J. Soil. Sci. 40: 707-717.

Mocek A., Owczarzak W., Kaczmarek Z. (1994): Degradacja fizyczna gleby przyczyną spadku plonowania roślin uprawnych [Physical degradation of soil as a cause of decreased crop yielding]. Roczniki AR w Poznaniu CCLX: 65-75.

Nowacki W. (2010): Ziemniak gatunkiem trudnym w uprawie narażonym na wysokie straty plonu handlowego [Potatoes as a crop difficult to cultivate and at risk of high losses of merchantable yield]. Progress in Plant Protection / Postępy w Ochronie Roślin 50(3): 1174-1180.

Pabin J., Włodek S., Biskupski A., Runowska-Hryńczuk B., Kaus A. (2000): Ocena właściwości fizycznych gleby i plonowania roślin przy zastosowaniu uproszczeń uprawowych [Assessment of physical properties of soil and crop yields with simplified cultivation]. Inżynieria Rolnicza 6: 213-219. 
Podsiadłowski S., Hagen L. (2000): An integrated tillage system to prevent pulverization and wind erosion of sandy soils. Tillage at the Threshold of the 21st Century: Looking Ahead. Proc. of 15th Conf. of the ISTRO. Fort Worth, Texas. Paper no. 00-71-O, 12.

Ordinance of the Minister of Agriculture and Rural Development of 29 October 2003 on specific requirements for commercial quality of potatoes (2003): Dziennik Ustaw [Journal of Laws] 2003, No. 194, item 1900.

Starczewski J., Droese H., Śmierzchalski L. (1984): Wpływ uprawy roli i zagęszczenia gleby na plony ziemniaków [The effect of tillage and soil compaction on potato yields]. Roczniki Nauk Rolniczych Ser. A, vol. 106, book 1: 65-81.

Strzemski M. (1972): Przyrodniczo-rolnicza bonitacja gruntów ornych [Natural and agricultural quality classification of arable land]. IUNG, Puławy.

Watts C.W., Dexter A.R. (1993): A hand-held instrument for the in situ measurement of soil shear strength in the puddled layer of paddy fields. J. Agric. Engng. Res. 54: 329-337.

Young I.M., Mullins C.E. (1991): Factors affecting the strength of undisturbed cores from soils with low structural stability. J. Soil Science 42: 205-217. 